\title{
MARKETING INFORMATION SYSTEMS IN THE HEALTH SECTOR: A PRACTICE IN HOSPITALS IN TURKEY AND JORDAN
}

\author{
Assist. Prof. Dr. Turan PEKMEZCi \\ Gaziantep University Management Organization \\ Assist. Prof. Dr. Yakup DURMAZ \\ Hasan Kalyoncu University \\ Department of Marketing \\ Master Student Othman ABDULWAHID \\ Gaziantep University
}

\begin{abstract}
Health tourism, showing development in the last twenty years in the world, has emerged as an alternative tourism. Health tourism, very quickly developing among alternative tourism options, is an important profit tool since it is increasing the number of business enterprises serving in this field. In this sense, marketing objectives set out in the health services is very diverse. The main objective of the health service is to determine accurately the demands of the target customer and meeting their needs and demands at the highest level to satisfy patients/customers.

In this research perception on marketing information systems of public and private hospital managers in Turkey (Gaziantep) and Jordan (Amman) was investigated and perception of patients sought medical treatment in the hospitals of these countries examined using the survey technique. It is confirmed that patients in these countries have different perceptions in terms of hospitals, general services, health services and customer satisfaction. According to the resulting data, there is no difference in perception of managers in these countries on marketing information systems.
\end{abstract}

\section{Keywords}

Marketing Information Systems, Health Tourism, Health Services and Customer Satisfaction.

\section{Council for Innovative Research}

Peer Review Research Publishing System

Journal: INTERNATIONAL JOURNAL OF COMPUTERS \& TECHNOLOGY

Vol. 15, No. 2

www.ijctonline.com, editorijctonline@gmail.com 


\section{INTRODUCTION}

Success of institutions and administration is linked with the decisions made and the accuracy and currency of the information used. Therefore organisations need to have sufficient communication and data processing systems. Information flow is achieved with research and communication in all business enterprises. Information gathered facilitates and accelerates marketing managers to understand the dynamics of the market.

Today managers of the enterprises have more opportunity to follow the change in the market thanks to direct communication with the consumers and determining their needs and requests. On the other hand increasing distance between producer and consumer and the growing number of intermediary institutions is increasing the uncertainty for the managers obliged to make correct decisions constantly.

Marketing research and marketing information systems provide information to fill the gap between producers and consumers in the dynamic and competing environment of the commerce sector.

Improvement of marketing strategy requires the deep analysis of the inner and outer structure of the business enterprise and synthesis of the useful information. Information gathered with the result of the analysis of the business enterprise's structure must be collected and configured in a way to form the base of marketing decision. Therefore converting the crude information to useful information; computers and marketing information systems which is the application of information systems in marketing niche are getting more and more important.

Marketing Information Systems (MIS) has become unavoidable with the formation of the new competing market, swift change and shortening the duration of decision making, more complex and extented financial and marketing methods, change in the consumers' habits and standarts, globallisation emerged from the information society era, development in the field of technology on data processing and analysis and finally improvement in the quality of the marketing experts and managers.

However the necessity of this kind of systems which can be life saving is not always appreciated by administrators. Administrators may not be aware of the necessity of developed MIS since they are glad with the present situation or they lack the ability to foresee the future. Because of difficulties in decision making, increasing number of defective decisions, insufficiencies towards abrupt and swift change in the market, crisis and related issues all employees and sections have to participate information gathering process (Yeşilada, Yeşilada ve Tanyeri, 2003).

\section{MARKETING INFORMATION SYSTEMS}

\subsection{Definition and Importance of Marketing Information Systems}

Marketing Information Systems, "In order to gather accurate information on time, store, extract, make it ready for the use, analysis, deliver it to the necessary places and evaluate by decision makers of marketing or its managers who are planning, performing and controling the marketing; person, device and procedures must be in constant harmony" (Kurtuluş, 1998).

\subsubsection{Enterprise Entries - Domestic Information Sources}

Number of marketing managers use enterprise domestic entries and reports while planning and applying daily marketing activity as they make use of domestic resources, client complaints, evaluation reports, order-sell cost reports. Marketing performance evaluation report, investigations on marketing problems, order-sell-cost-cash flow reports, sellmarket evaluation reports, balance sheet and charts are among many other.

\subsubsection{Observation Information}

Market observation information such as observations on daily market activites, advertisements on mass media, marketing activities of opponents will be hepful for marketing managers while preparing and updating marketing plans.

\subsubsection{Marketing Researches - External Information Sources}

Marketshare, client satisfaction, studies on customer's habits are among external information sources of marketing information systems. Unlike market observation information, marketing researches require precise research on a definite topic.

\subsection{Scope of Marketing Information Systems}

In modern-day enterprises, It is difficult to make dynamic decisions for marketing managers. Factors which make Marketing Information Systems unavoidable and reaching reliable and accurate information on time as follows:

- Shorting in product life time,

- Obligation of decision making and swift response,

- Market activities which became complex and larger scope,

- Obligation of effective usage of raw material resources,

- Increased expectaions,

- Consumers' unsatisfaction and etc. 
Marketing Information Systems basically possess three duties: (Altunışık vd. , 2004).

- Determining information needed by marketing managers,

- Generating information needed via information resources,

- $\quad$ Presenting generated information on preferred time and form to decision making process.

\section{HEALTH TOURISM AND HEALTH SERVICES}

Health tourism which can be defined as planned travel from native country to another country to receive health service such as diagnosis, medical treatment or care has become popular sector in modern-day Turkey.

From this point of view strategic plans of Ministry of Culture and Tourism, Ministry of Health, Ministry of Development and Economy also cover health tourism.

\subsection{Definition and Importance of Health Tourism}

Concept of health tourism can be defined as people's travel form their permanent residence to the places which provide health services in order to solve their health problems and receive medical treatments and temporary usage of health institutions in the destination(Aydın, 2009: 22).

Health tourism is briefly journey for medical treatment. In other words it is a tourism type which enable development of health institutions with using patients in need of medical treatment and rehabilitation and international patient potential. (Establishment Report and Solution Proposals of Health Tourism in Turkey and in the World,p.,2010: 52).

Benefit of health tourism on countries can be examined perceptibly or abstarctly:

Some of the obvious benefits include contribution of incomes from foreign toursits to countries' financial welfare, increase in cooperation among countries and development of strategical partnerships, contribution to information and technology flow among countries, advance in the level of medical treatment of local patients thanks to progress in the level of medical treatment towards foreign tourists because of high international competition. (Annette B, de Arellano R. 2007).

Some of the abstract benefits include sharing social and cultural experience, conributing the improvement of international relations, development of global marketing and medical trade, improvement in the image of health care service, providing competetive advantage, empowering partnership between public and private sector in healthcare field, extending patient satisfaction in different aspects. (Annette B, de Arellano R. 2007).

\subsection{Components of Health Tourism}

At the present time types of tourism altering because of persons' intent, demand, interest and hobbies, thriving with innovation in different areas, on the other hand health tourism started to serve modern people who see healthy life as a life style and value their physical and mental health (Aydın, 2012:.93).

As one of them medical tourism, groving rapidly in the tourism industry, is a concept which refers the journey of people to distant countries for medical therapy and at the same time being holidaymakers. This is not a new concept. Especially health tourism for hair transplantation, cornea operations and dental treatment may include travel for cultural porposes. Health tourism is integrated with special pleasure tours in the host country for patients. Apart from the high medical treatment costs in the developed countries, in health tourism people get high standard medical applications with relatively high technology and at the same time decent holiday (G. Garcia, M. Besinga, 2006). 


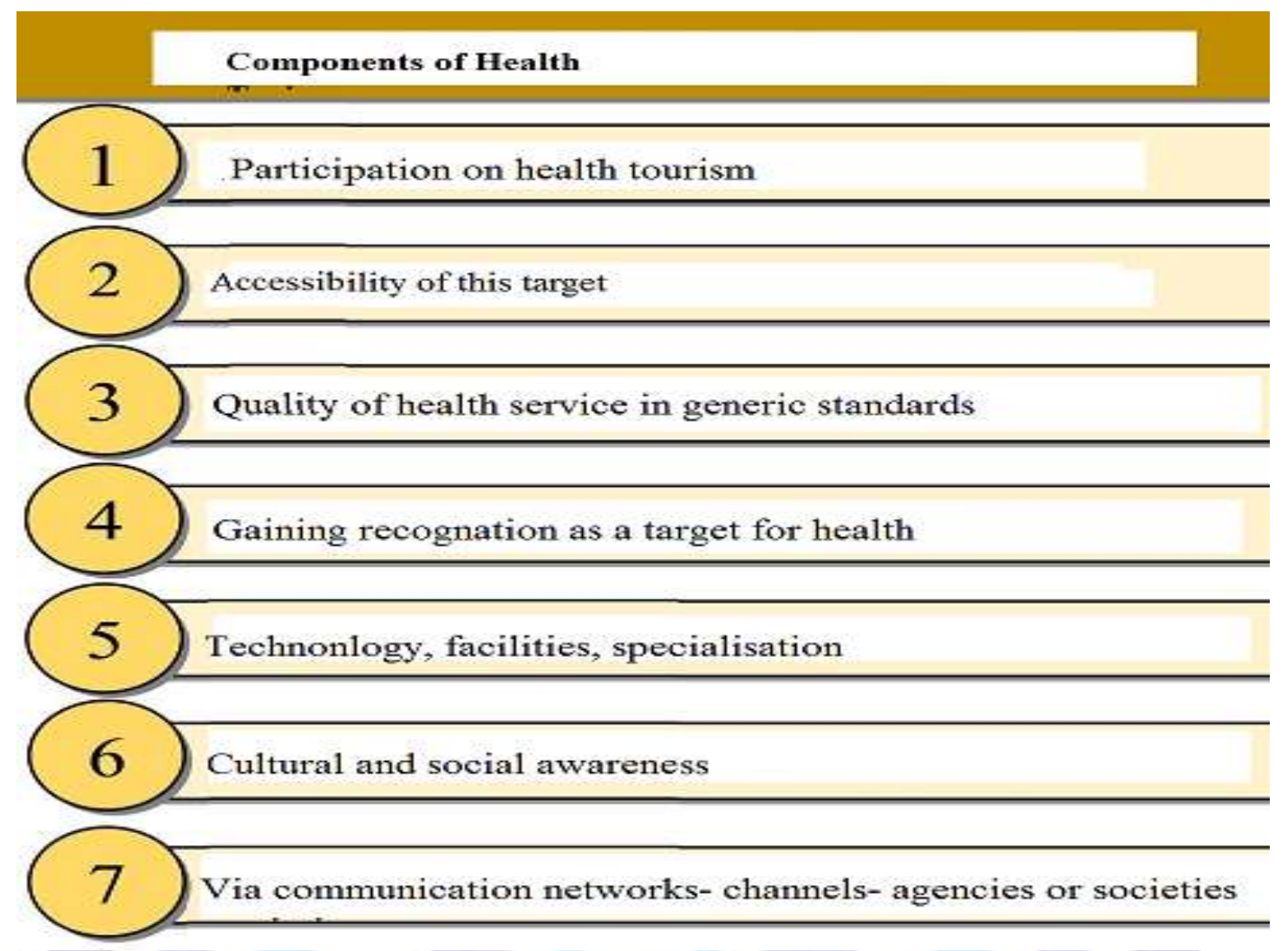

Figure 1: Componenet Health Tourism

http://www.slideshare.net/iagprem/review-of-medical-torism-destinations-by-dr-prem-jagyasi

\subsection{Perception, Recognition And Branding In Health Tourism}

There are five different types of treatments in health tourism (Nandi, 2012: 6).

The First Type of Health Tourism: People are striving to find different places to get high quality service with consideration cost, lack of attention, modern technology and superior equipment. According to a study $\% 40$ of people are preferring other countries for medical treatment. Travel to the developed countries for medical treatment is an example.

The Second Type of Health Tourism: The ratio of people seeking service and special care in their native countries is \%32. Citizens of India, as an developing country, get service in that ratio. In a study in India American researchers investigated problems and difficulties of journey for medical issues in this country and they concluded that people's first priority is the cost.

The Third Type of Health Tourism: According to the study conducted issues like preventive activities and access speed cover \%15 but it is mostly preferred to prevent heart and bone diseases complicaitons.

The Fourth Type of Health Tourism: The ratio of the ones who give priority to cost and calculating the cost for the service is \%9.

The Fifth Type of Health Tourism: The number of the people who find the fees relatively expensive or exceeding their income level is $\% 4$ and it is observed that some of these patients preferred it for cosmetic reasons.

Health tourism has shown rapid growth in the last decade. India, Costa Rica, Hungary, Turkey, Lithuania, Israel, Jordan, Thailand, Malaysia, South Africa and Cuba are the leading countries interested in health tourism.

\section{CONCEPT OF CUSTOMER AND PATIENT AND CUSTOMER SATISFACTION}

After the new millennium in our world we see incredible changes in the organisation and presentation of health services. Everyday new tools and methods are invented. Half of the present knowledge expires within five years. Health related business enterprises will be dominant in the third millennium. Because foundation and operation of health institutions which host extraordinary complicated systems is alone problematic. As stated in the publications prepared in the USA health sector is the sector most intensively use technology only after space technology. This situation also include the answer of the question why inverstments in the health services are at a high cost (Yerebakan, 2000: 9). 
Customer satisfaction can be defined as "conveying the desired quality product or service to customer timely and at a low cost" (Kaya, 1997:1). Comprehending the customer satisfaction is very important for the business enterprises which do not afraid of customers, believe in the importance of mutual communication, do not ashamed of failures and see failures as an opportunity to learn (Barış, 2008: 22).

The Importance of Patient/Customer Satisfaction, Concept of satisfaction after a health service has become an important issue recently. There is a wide and heterogeneous customer group that health institutions required to satisfy. In the past customers of health institutions were only patients but today all individuals and institutions within the production process of health services are accepted as customers (Çakıl, 2007: 141).

\section{MATERIAL AND METHOD}

The purpose of this section of the study, scope, methods and generated hypotheses it is located.

\subsection{Aim Of The Research}

Aim of the research is to analyze the perception of hospital managers in Turkey (Gaziantep) and Jordan (Amman) on marketing information systems and after that to analyze opinions of hospital managers in both countries on marketing information systems and perception of patients, sought medical services in these countries, on the mentioned hospitals.

\subsection{Extent Of The Research}

This research was conducted in January and February of 2015. This research comprises managers of the hospitals in Turkey (Gaziantep) and Jordan (Amman) and the patients sought medical services in these hospitals. Extent of the research subject is limited with the subject of the research. The constraint of the research is preliminary acceptance of research participants' statements are genuine.

\subsection{Method Of The Research}

Questionnaire comprise of two parts for patients and hospitals. For patients in the first part there are 6 questions to participants on general services, 5 questions on health services and 9 questions on customer satisfaction and there are 20 questions in total.

In the second part 22 questions asked to the participants on "marketing information systems in the hospital". The total number of the questions is 42 .

The research was conducted on the relation between marketing information systems in health tourism and customer satisfaction. Social media applications (e-mail, facebook, twitter etc.) or direct survey method is applied in this research. Survey questions generated by using GOOGLE FORMS software and they are distributed electronically. Obtained arithmetic average, standard deviation, percentage ratio and number of repetition alayzed using SPSS software, hypothesis assessed using EXCELL software. Using sample research results illustrated with comparison graphics.

\subsection{Hypothesis Of The Research}

Hypothesis developed in order to investigate marketing information systems in health tourism and customer satisfaction are as follows:

H1: In Turkey and Jordan hospital managers' perception on marketing information systems is different.

H2: Patients sought medical care in Turkey and Jordan have different perception on hospitals.

H2a: Patients sought medical care in Turkey and Jordan have different perception on the general services at the hospitals.

H2b: Patients sought medical care in Turkey and Jordan have different perception on the health services at the hospitals.

H2c: Patients sought medical care in Turkey and Jordan have different satisfaction level.

\section{RESULTS AND DISCUSSION}

Revealing the findings in this research has been done on the basis of analytical comparison approach using comparative survey method. Researcher carried out the research in order to reach the primary information working in the field of application and using the information and data obtained from the sample by analyzing the hypothesis put forward in the light of the work.

Research group and sampling; 300 questionnaire questions distributed through social media (face book, twitter, e-mail) and some of the patients interviewed in person. 285 of patients have answered the survey questions. Therefore, the participation number of the analyzed survey is 285 and total participation rate in the survey is \%95. 285 patients took part in this survey selected randomly. The sample of the research consisted of patients in different countries (Iraq - Syria - Jordan - Egypt - Saudi Arabia - Turkey). Analysis includes patients, come from different countries, receiving treatment in public and private hospitals in Turkey and Jordan. 


\section{CONCLUSION AND SUGGESTIONS}

H1: In Turkey and Jordan hospital managers' perception on marketing information systems is different.

As to "Application of marketing information systems in hospitals provide fast service production and saves time" the researcher observed that hospital management in Turkey has a great trend on the use of general information systems and techniques. The reasons for this are elimination of the hospitals in Syria, Iran and other Arab countries with the consequences recent political unrests, increase in the need for Turkish market in the field of health tourism for patients in neighboring countries and various Arab countries in the region and the prevalence of social health insurance systems in our country for foreigners living in our country.

Besides it should also be stressed that tourists arriving Turkey for health tourism or normal tourism encounter with relaxed tourism atmosphere. Because of these reasons the hospital management in Turkey predicting future expectations about the health services were found to pay more attention to the use and marketing information systems to meet the changing demands.

H2: Patients sought medical care in Turkey and Jordan have different perception on hospitals.

\section{A. General services aspect}

Today it is possible to reach the services offered by the hospital in various languages thanks to the internet as one of the widespread competition tools and it has an affect on patients's preferences for medical care. This can also be seen in the difference between the arithmetic data on both countries $(2.658,2.257)$.

Overall t-test value is 5.551 while t-test mean value has emerged as 0.000 .

Therefore, as a result there are noticeable differences in general services. This is lower than the probability level of 0.05 . As seen in the arithmetic average data $(2.194,1.792)$, in conclusion a big difference emerged between hospitals in Turkey and Jordan and for general services it is seen that patients preferred hospital in Turkey.

\section{B. Health services aspect}

Capacity of hospitals to solve problems faced by patients and their relatives during their stay in hospital for treatment have a favorable effect on the preferences of patients. As can be understood from the small difference between arithmetic average $(2.266,2.058)$ and standard deviation $(0.887,0.943)$ the hospitals in both countries place importance on this issue.

Overall t-test value is 0.827 while t-test mean value has emerged as 0.410 . Therefore, as a result there is no appreciable difference in health services. This is higher than the probability level of 0.05 . Overall preference of patients on health services is Turkish hospitals. This result can be seen from the comparison between the standard deviation $(0.592,0.571)$ and arithmetic average $(2.208,2.271)$ and the general differences emerged.

\section{Patient satisfaction aspect}

Patients sought medical treatment in both countries satisfied with the service they received, and this satisfaction is reflected in their positive recommendation of medical services to other patients. However, the arithmetic average value of hospitals in Turkey seems to be higher than the Jordanian hospital. There is not a considerable difference between the standard deviation data $(2.124,2.2616)$. In other words despite value of Ttesting mean is higher than 0.05 , there are no significant differences in customer satisfaction in Turkey and Jordan $(0.62479,0.51383)$.

As a result, there is a compromise on customer satisfaction and health services for both countries, we can rule out the accuracy of the second hypothesis since as to general services there is a different perception among health tourism customers.

\section{SUGGESTIONS}

- Marketing information systems to help hospitals improve their performance levels and provide efficient services.

- Marketing information systems can be used to improve decision-making and problem solving processes of hospital management.

- Marketing information systems should be employed to facilitate sufficient electronic communication network linking all hospital staff.

- An effective usage of the marketing information systems can identify the expectations of domestic and foreign patients in terms of providing services and contribute to customer satisfaction.

- It can be used to provide communication between hospitals for the services after the treatment, especially for foreign patients to go to hospitals in other countries.

- The presence of several laboratories in a hospital and offering all services within a hospital can contribute to the patients not to pay high costs and on the other hand contribute to the hospital's budget.

- Hospital must act knowing that patients have the legal rights about medical treatment and right to choose physicians and on the other hand patients should be aware of what to do in the face of a negative situation. 
- Hospitals should constantly follow health service standards in various countries of the world and the newly opened health departments and they should seek the ways to offer the best service to satisfy customers.

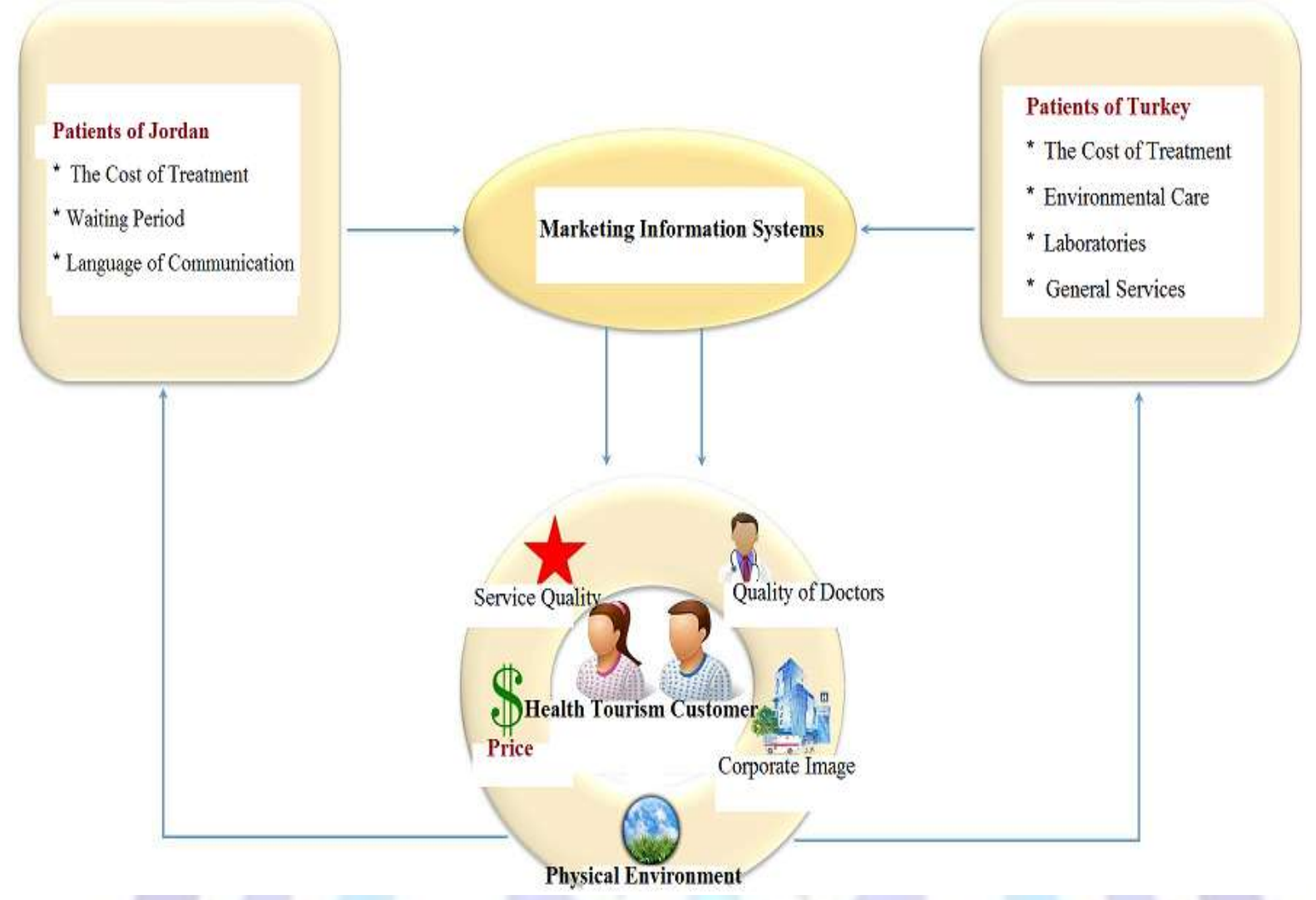

Figures 2: Marketing Information Systems

\section{REFERENCE}

Aaker, David, A. (1992). "Strategic Marketing Managment", Third Edition, Jhon

Wiley and Sons Inc., Canada.

Akyol D.A. (1993). Hemodialize giren hastaların verilen bakımdan memnun olmalarının değerlendirilmesi, Uluslar arası Kalite, Maliyet ve Hemşirelik Sempozyumu Kitabı, İzmir, Ege niversitesi Basımevi, s. 80-91.

Alabay, M.N. (2008). CRM Rekabet Stratejisi Olarak Müşteri İlişkileri Yönetimi”, İlke Yayınevi, Ankara.

Annette B, de Arellano R.( 2007) Patients without borders: the emergence of medical tourism International Journal of Health Services;37(1): 193-8.

Apaydın, F. (2009). "Sa lık şletmelerinde Marka Yönetimi”, Sa lık şletmeleri Yönetim Rehberi, Seçkin Yayınevi, Ankara.

Armutlu, C.,Mithat M., (2009). "Benlik majı Uyumu, Tüketici Tatmini ve

Marka Sadakati lişkisi zerine Görgül BBir Araştırma”, Gazi niversitesi BF Dergisi, Cilt 11, Sayı 3.

Bohrer, Monty F., (2007). "Discriminant Analysis of Aaker's Brand Equity Model on

Top-Of-Mind Awareness/Brand Preference Congruence In Propective Hospital

Patients", Anderson University, Doctor of Business Administration.

Burns, Alvin C., Bush, Ronald F. (2000). Marketing Research, 3rdEd., Prentice-Hall,

Corbin, C.L., Kelley, S.W., Schwartz, R.W. (2001). "Concepts in Service Marketing for Healthcare Professionals", The American Journal of Surgery, 181.

Çakıl, E. (2007).“Sağlık Hizmetlerinde Hasta Memnuniyetini Etkileyen Faktörler” TıpAraştırmaları Dergisi, 5(3), ss. 140- 
143.

Garcia, A.G., and Besinga C.A.M. (2006). Chalanges and Oppurtinities in Philippine

Medikal Tourism Industry. The SVG Review, June, 41-55.

Gülmez M. (2005). Sağlık Hizmetlerinde Memnuniyet Ölçümü ve Cumhuriyet

Üniversitesi Araştırma Hastanesi'nde Ayakta Tedavi Gören Hastalara Yönelik Bir Uygulama, C. . ktisadi ve dari Bilimler Dergisi, Cilt 6, Sayı 2,

Işık, O. (2011). "Algılanan Kalitenin Hastane Marka Değerine Etkisi: tüketici

De erlendirmesi”, Ankara, Gazi Üniversitesi Sosyal Bilimler Enstitüsü

Yayınlanmamış Doktora tezi, Ankara.

Kavuncubaşı, Ş., (2000). "Hastane ve Sağlık Kurumları Yönetimi”, Siyasal Kitapevi,

Ankara.

Kennett, P.A., Henson, S.W., Crow, S.M., Hartman, S.J. (2005). "Key Tasks in

Healthcare Marketing: Assessing Importance and Current Level of

Knowledge", Journal of Health and Human Services Administration, Cilt: 27,

Sayı: $3 / 4$.

Kısa, A., Tokgöz, N. (Ed), (2007). "Sa lık Kurumları Yönetimi”, Anadolu Üniversitesi Açık ö retim Yayınları, Eskişehir.

Koçak, ., Yalçın, S., (2009).”Ni de Devlet Hastanesinde Müşteri memnuniyeti Üzerine Bir Araştırma", Niğde Üniversitesi BF dergisi, 2(2), ss. 19-41.

Kotler P. (2000). “Marketing Management-Pazarlama Yönetimi”, Çeviren: Nejat Muallimoğlu, Beta Basım, İstanbul.

Laudon, K.C., Laudon J.P. (2002). Management information systems: Managing the digital firm (7th Ed.). Prentice-Hall Inc.,

Mucuk, I . (2004). Pazarlama lkeleri, 14. Basım, Türkmen Kitabevi, İstanbul.

Mutlu, A. Işık, A.K. (2006). Sağlık Ekonomisine Giriş, Bursa: Ekin Yayınları.

Odabaşı, Y. (1994). Sağlık Hizmetleri Pazarlaması, Eskişehir: Anadolu Üniversitesi

Yayın No:799, Açıkögretim Fakültesi Yayın No:409.

Öztürk, Y., (2002). Gelişmekte olan ülkeler için alternatif turizm faaliyetleri üzerine teorik bir çalışma. Ticaret ve Turizm Eğitim Fakültesi Dergisi;5(2):183 95.

Pekmezci T. (2011) "Pazrlama Araştırması" Lisans Yayıncılık Bayrampaşa İstanbul .

Raymond, L., Brsoux, J., Azamı, A. (2001). "Marketing Information Systems Practices

In Small Manufacturing Firms: Antecedents and Consequences, The Journal of

Computer Information Systems", ProQuest Computing, Vol.41, No.3.

Sevindik, E. (2007). "Marka De eri Içümleme Metotları ve Lastik Endüstrisinde Bir

Uygulama", Marmara niversitesi Sosyal Bilimler Enstitüsü Yayımlanmamış

Yüksek Lisans Tezi, İstanbul.

Şahin. (2002): "Pazarlama Denetimi Sağlık Hizmetleri Organizasyonları için Bir

Araç”, Modern Hastane Yönetimi, Cilt 6, Sayı 1, Ocak-Şubat-Mart, s.19-23.

Şimşek, M.Ş. (2007). İşletme Bilimlerine Giriş, Yelken Basım Yayın Dağıtım, Konya.

Tek,Ö mer Baybars (1991). Pazarlama: Ikeler ve Uygulamalar, Memleket Matbaacılık, İzmir.

Tengilimo lu, D., Işık, O., Akbolat, M. (2011). "Sağlık İşletmeleri Yönetimi”, Nobel

Yayın Da ıtım, Ankara. 